\title{
The Christian faith and evolution: An evolving, unresolved debate
}

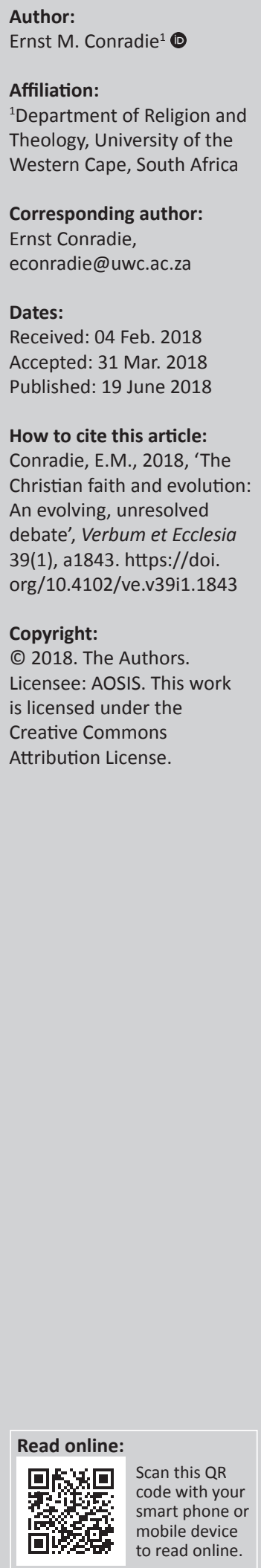

This article sketches how the debate on Christian faith and evolution has evolved. Seven challenges are identified and described in the debate, namely, regarding a recognition of deep (geological) time (challenging the historicity of the biblical creation narratives), understanding the role of chance in natural selection (posing questions about the nature of divine action, e.g., providence), human descent (challenging presumed human distinctiveness), a recognition of natural suffering (challenging the benevolence of the Creator), identifying the evolutionary roots of evil (challenging Christian views on the fall of humanity), a recognition of natural disselection (challenging notions of divine election) and, finally, evolutionary explanations of the emergence of morality and of religion (reiterating the challenge of atheism). It is argued that with each of these challenges, some of the underlying problems were provisionally resolved, only to reappear later in an even more challenging form.

Intradisciplinary and/or interdisciplinary implications: The contribution describes shifts in Christian discourse on evolution and challenges the tacit assumption that any one aspect of the debate has been fully resolved by articulating some of the questions that have been resolved and others that remain unresolved.

\section{Introduction}

There is a huge and rapidly expanding corpus of literature on the relationship between Christian theology and evolutionary biology. There have been several attempts to offer a typology of approaches adopted in this debate. These typically range between conflict (adopted by creationists and atheists alike) and conflation (seeking to reinterpret the Christian faith in categories derived from evolutionary theory, e.g., by following Teilhard's or Whitehead's leads) or (inversely) to offer an ultimate explanation of nature's evolutionary character in terms of God's character.

In this article I will not take seriously the extremes of (scientific) creationism, intelligent design or militant atheism using scientific evidence to support reductionist metaphysical positions. There are ample critiques of such positions available in the literature. It would also be overly bold to offer an overview of constructive literature on theistic evolution (seeking to make sense of the Christian faith in ways that would be compatible with evolutionary history) or on evolutionary theology (seeking to boldly offer a theological interpretation of evolution). I will touch upon, but not explore debates on ontological reductionism, evolutionary epistemology or the relationship between brain and mind that are often discussed by theologians but that are not particular to debates on evolution and the Christian faith.

Instead, I will adopt a more limited approach, namely, to offer some observations, painting in rather broad strokes, on the challenges that the very notion of evolution poses to the Christian faith. The task is to identify and describe the agenda but not to address such an agenda as further references could be multiplied. ${ }^{1}$ I will argue that there are marked challenges in the evolving

\footnotetext{
1.For a similar description of the state of questioning, see Gijsbert van den Brink's detailed study (2017). I developed this survey independently but obviously benefited from his analysis. His agenda is to explore where there might be points of conflict between mainstream evolutionary biology and orthodox understandings of the Christian faith. He identifies especially six such presumed conflicts but argues in each case that there is no necessary conflict and that Christian theology and evolutionary biology each offer a distinct perspective on the same history, that sometimes overlap with each other and in some cases can mutually illuminate each other. By recognising such distinct perspectives he seeks to recognise the influence of shifting worldviews and to avoid category mistakes by conflating science and theology. The six challenges that he identifies are correlated with three aspects of evolution: (1) the geological time scale of evolution (posing problems for biblical hermeneutics and for an affirmation of the goodness of the Creator given sufferin time scale of evolution (posing problems). (2) human long before the emergence of humans); (2) human descent (posing problems for an affirmation of human dignity on the basis of the 'image of God' and for the emergence of human sin), and (3) natural selection as the main mechanism for evolution (posing problems for understanding God's sovereignty given the role of rando emergence of culture, morality and religion). In this article, I have rearranged the agenda by identifying and describing broad challenges, while not seeking to adopt any substantive position on any aspect of this agenda. My aim is to show why each of the debates remains unresolved while Van den Brink's aim is more apologetic, namely, to argue that there is no necessary conflict between orthodox (reformed) beliefs and evolutionary biology. We agree that science and theology offer perspectives on the same evolutionary history and seek to interpret that. This suggests the need for 'traction' (to address any incompatibilities of theological constructions with scientific evidence) and also for plausibility (do theological perspectives actually help to make sense of such history?).
} 
debate and that in each case some of the underlying problems were provisionally resolved (arguably so), only to reappear later in an even more challenging form and in such a way that the debates remain unresolved. ${ }^{2}$

\section{An evolving universe?}

James Ussher (1581-1656) famously calculated that the first day of creation was Sunday 23 October 4004 BC, while Adam and Eve were driven from Paradise on Monday 10 November $4004 \mathrm{BC}$, and that the ark touched down on Mt Ararat on 05 May 2348 BC on a Wednesday. John Lightfoot, vice-chancellor of the University of Cambridge, added that 'heaven and earth, centre and circumference, were created all together, in the same instant' and that humankind was created by the Trinity on 23 October 4004 $\mathrm{BC}$, at $9 \mathrm{o}^{\prime}$ clock in the morning. ${ }^{3}$

Although there was some serious scholarship behind such calculations, this is nowadays met with ridicule and anachronistically dismissed as creationist. The recognition of an evolving planet and indeed an evolving universe required centuries of scientific labour. Christian theologians were at best reluctant to acknowledge shifting geological dates for the age of the Earth as this seemed to undermine the plausibility of the biblical creation narratives. Such resistance may well have harboured Platonic or Aristotelian (Thomistic) inclinations to regard change as inversely proportioned to truth. If so, history and life itself implies some form of alienation from God's eternal intentions. A more historical (whether Hebraic, Hegelian, Marxist or Darwinian) notion of truth was not easy to come by.

The theological debate on a more historical understanding of truth has not been resolved though. There are clear dangers associated with historicism and absolutism (understanding the Christian faith in terms of some abiding features of human existence) ${ }^{4}$ as well as with historicism and relativism (seeing the particularity of the Christian story merely as one story among many others). These modernist and postmodernist challenges have prompted a shift away from medieval (Catholic) scholasticism and also from Protestant scholasticism, albeit not yet in fundamentalist, evangelical and Pentecostal circles. Narrative theology would regard Christian doctrine as 'condensed narratives', but the many modes of narrative theology (found in neo-orthodox, radical orthodox, liberal and postliberal theologies alike) suggest ongoing methodological debates in this regard. Such an emphasis on narrative can help maintain a certain historicity that is crucial for the Christian faith on condition that narrative is not separated from history. However, this then raises the question, whether theological perspectives have some 'traction' with scientific perspectives

2.For an earlier version of my description of such shifts, see Conradie (2013b)

3.See https://www.lhup.edu/ dsimanek/ussher.htm (accessed 28 October 2017).

4.See Van den Brink (2017:133-134) in conversation with the work of Denis Lamoureux. Van den Brink recognises that understanding the Christian faith in Lamour oux. Van den Buth recognises that understanding the Christian faith in (evolutionary) history cannot be withdrawn from the (evolutionary) history cannot be withdrawn from the sphere of God's actions. He suggests that theological and scientific perspectives overlap with each other on this point and cannot be regarded as completely incommensurable (Barth) or as nonoverlapping magisteria (Gould). on the same history. As both sets of disciplines seek to interpret the same evolutionary history, the notion of non-overlapping magisteria cannot be maintained. It should also be noted that this theological debate is mirrored in the field of biblical hermeneutics, where Biblicism and concordism may be widely discredited (see Van den Brink 2017:110-141), while purely contextual readings of the biblical texts seem to undermine the cosmic scope of the story and to provincialise its meaning prematurely. Such hermeneutical debates are not addressed in this article in any detail as this deserves a more fully developed treatment.

One may presume though that the recognition of an evolving universe and of the evolution of species is widely accepted in contemporary theological debates. Nowadays it is hard to find anyone outside the circles of creationists who does not 'believe' in evolution. Admittedly, 'belief' is scarcely the appropriate term here, but evolution is surely also 'more than a mere hypothesis'. The evolution of species is as close as one could get to a biological fact, while natural selection as a driver of evolutionary change is a well-established scientific paradigm supported by a wealth of scientific data. There can be no debate on creation or evolution as evolutionary theories do not address questions on the origin(s) of life, rather only on its further development. At best a conversation is possible on evolution and ongoing creation or providence (Van den Brink 2017:60). By contrast, the debate on intelligent design as a position on the so-called fine-tuning of the universe concerns an understanding of creation and, if applied to evolution (to account for the complexity of the human genome), falls into the trap of a God who fills in any remaining gaps in scientific knowledge. Claims to have direct access to such knowledge through divine revelation constitute a shortcut that bypasses painstaking scientific processes and undermines theological credibility.

The very 'fact' of evolution is still hard to fathom though. The Hebraic recognition is that God as Creator is the one who instigates change, brings forth life and death, and calls for transformation. This is a God who risks, a God of history who is therefore necessarily vulnerable. The very notion of a God of life, a living God, remains hard to understand given the biological evidence indicating that life presupposes death as a thermodynamic necessity and prerequisite for regeneration (see Conradie 2013b; Peacocke 2001:35; Southgate 2008:8; Conradie 2013b). The Christian witness is of course that God became incarnate in Jesus Christ, and in this sense, that 'God' was crucified and died. This still shocks the sensibility even of those who welcome the notion of an evolving universe.

Moreover, when seen through a wider lens than narrow debates on creationism, one may say that coming to terms with the very notion of evolution is a challenge that Christian theology has scarcely come to terms with. The same applies to science, philosophy and the arts though. We may all eagerly agree, with Holmes Rolston (2010), to recognise three 'big bangs' in cosmic origins, the evolution of life and the emergence of humanity. However, the very meaning of an evolving universe continues to baffle those seeking to 
understand it. These are the truly perplexing questions in life, questions about origins, destinies and our place in the history of this planet and in cosmic history. Secular scholars have probed the meaning of this history, but they too end up in informed speculation - about string theory, the anthropic principle, the heat death of the universe and extraterrestrial life. Theologians have the added task to reflect on the mystery of history (see Conradie 2015): What is God really up to? The mystics and the prophets have given diverging answers but none would suffice. Those who rightly dismiss creationism need to admit that they are none the wiser. One may follow the leads of Hegel, Marx, Whitehead, Teilhard, Bloch, Moltmann or Pannenberg, but this debate clearly remains unresolved too.

\section{The role of chance in natural selection?}

Charles Darwin did not introduce the notion of evolution. With the gradual recognition of the age of the Earth and the accumulation of fossil finds, there was already wide acceptance that species became extinct and that they emerged at different epochs in the history of life on Earth. Darwin's theory was on the main mechanism for the origin of species, namely, natural selection. As Darwin realised, this required a gradual, step-by-step process and therefore a sense of deep time, but he painstakingly provided evidence in support of the theory that natural selection is the (main) driver of the evolution of species. The neo-Darwinian synthesis provided further support for his thesis by recognising the role played by genetic variation (in terms of DNA) as the vehicle upon which natural selection is exercised, leading to mutations and eventually to species bifurcation.

Theologians tend to struggle to come to terms with natural selection more than with the recognition of evolution. There are especially two reasons for this: the role played by chance (given natural variation) instead of intentional agency and 'selection' in terms of fitness to survive. I will return to the second aspect below. The Christian belief in God as the triune Creator suggests that the act of creation was a wilful decision by God. Orthodox dogmatics maintain that creation became possible on the basis of an eternal decree in the divine counsel. It has to do with divine agency and therefore with intention. Creation requires creativity and this is no passive or automatic process. Such an emphasis on intentional action gives rise to many further questions as to why God created for God's own glory (see Southgate 2014), out of love (see Moltmann 1985), for the fun of it (see Van Ruler 2009) - but the assumption that creation required a decision from God was never in doubt.

Darwin's emphasis on natural selection was quite radical given that evolution could be described as an unintentional process. It clearly challenged William Paley's notion of evidence of design that points to a divine Designer. Evolution is based on chance as heritable (genetic) mutations follow from random variation at the molecular level of DNA that is not directed towards better adaptation. The crux of the matter is that the mechanism of variation is causally unrelated to the processes of selection (see Peacocke 2004:51). Such mutations have no overall sense of purpose or direction, not to mention design or progress (see also Peters \& Hewlett 2003:48). It is not really a matter of 'selection' (surely a misnomer) but of a failure, because of inadaptability, to survive long enough to procreate - or the opposite. On this basis it seems that chance (random mutations) offers a more plausible and complete explanation of evolution than design or intentionality. Atheist critics like Richard Dawkins (1996) are quick to point out the theological implications: the watchmaker is 'blind'; in fact, there is no watchmaker. The assumption is that the role of 'pure chance' excludes any teleology also in a metaphysical sense and indeed that the chance embedded in mutations has metaphysical implications (that are thus imposed on the scientific data see Van den Brink 2017:274).

Some theologians responded to this challenge by seeking to defend the notion of overall design, even if some of the details of the evolutionary process may be governed by natural selection. More recently, such an emphasis on design became hardened through what is known as 'intelligent design'. The argument of intelligent design theorists is that the chances for the existence of the universe and the emergence of life are so infinitesimally small that the presence of a designer offers a more plausible explanation of life. Although such a notion of intelligent design remains popular in Christian circles, it is widely discredited by theologians seeking to take seriously the challenges posed by evolutionary biology (see, e.g., Peters \& Hewlett 2003). The main argument is that such a notion of intelligent design assumes a God who could fill remaining gaps in scientific knowledge, gaps that may well be filled by science in future. Such a shortcut can only undermine theological conversations with the biological sciences.

In response, those who affirm some form of theistic evolution typically state that natural selection is the mechanism that God used to create new organisms. This is best described in terms of continuing creation and with regard to the evolution of life and not so much the elusive origins of life. Evolution is God's way of creating. It is the way God did it (see Peters \& Hewlett 2003:155, with reference to Russell 1998). God makes things in such a way that it enables them to make themselves (according to the famous saying of Charles Kingsley). On the basis of this affirmation, a strong chorus of contemporary Catholic theologians, including Denis Edwards, Celia DeaneDrummond, John Haught and Elizabeth Johnson (see 2014:122-153), offers a theological vision of this evolving world as God's dwelling place.

This rather facile response is probably a necessary one in order to maintain faith in God. It sets the agenda to account for divine action in an evolutionary world, a theme that elicited considerable attention in science and theology discourse. It is impossible to offer an overview of such 
literature here. Suffice it to say that prominent scholars such as Philip Clayton, Denis Edwards, George Ellis, John Haught, Nancey Murphy, Arthur Peacocke, John Polkinghorne, Robert John Russell, Christopher Southgate, William Stoeger, Thomas Tracy, Keith Ward and Wesley Wildman have grappled especially with this problem in diverging ways. ${ }^{5}$

It should also be noted that at least some form of purpose or intentions is reintroduced. This still evades the problem of the role of chance. This famously bugged Albert Einstein (albeit in the field of quantum indeterminacy): does God play dice? Put in theological vocabulary: does the role of chance not undermine an affirmation of God's sovereignty and providence? Or as the anthropic principle suggests, was the dice loaded? Who loaded the dice (see Peacocke 2004:130)?

More recently, theologians seeking to engage with the challenges associated with evolution have recognised the need to understand the interplay between chance, law and intentional action. God creates through the interplay of chance and lawfulness (Edwards 1999:45, Ward 1996). There is no need to deny the role of chance as long as the interplay can be maintained because that is what is so creative. ${ }^{6}$ Human couples may be fully intentional in their decision to start a family. However, they cannot control conception or the sex of the foetus and are quite happy to leave that to chance while having fun in making love repeatedly until conception occurs. After conception they hope that the development of the foetus will follow established paths (law-like development). In raising their children there also needs to be an interplay between intentional planning, rules (or laws), while leaving crucial aspects underdetermined. They have to wait and see how things develop. It is not difficult to extrapolate such thought patterns to the way in which God creates and interacts with his beloved creation. Many would suggest that leaving things undetermined would be exactly what one may expect from a God of love and the inherent vulnerability that loving relationships entail (see Gandolfo 2015). God's letting be allows for 'a world percolating with contingency rather than one rigidified by necessity' (Haught 2000:40). The role of chance does not undermine God's sovereignty as they operate at different levels of causation. ${ }^{7}$ God may well take a chance on chance.

5.Given the enormous size and scope of the available literature, it would be inappropriate to select some and disselect other contributions. See my overview of such debates in the Afrikaans monograph Lewend en Kragtig? (Conradie 2010) and in Chapter 4 of The Earth in God's Economy (Conradie 2015).

6.Elizabeth Johnson (2014) puts this well:

If all were law, the natural world would ossify; its ordered structure would be rigid, repetitive, deterministic. If all were chance, nature would dissolve in chaos; no patterns would persist long enough to have an identity. But chance operating within a lawlike framework introduces novelty within a pattern that contains and directs it. (pp. 170-171)

She interprets this pneumatologically (2014):

A boundless love at work in the universe, the Spirit embraces the chanciness of random mutations, being the source not only of order but also of the unexpected breaks in order that ensure freshness. p. 173)

Likewise, Denis Edwards (1999:78-100) focuses on the Holy Spirit as the Giver of Life in describing 'The God of Evolution'.

7.See Edwards (1999):

It is quite possible to think theologically of God as working purposefully in the universe through processes such as random mutation and natural selection, which when investigated empirically does not reveal purpose at all. (p. 47)
However, note that such a theological position presumes that evolution is not only determined (?!) by chance. This assumes some role for intentional agency to account for the directionality (but not the progressive nature) of evolution. As John Haught (2000) insists:

Without too much difficulty, we can make out a kind of story line along which nature has traveled from trivial to more intricate and eventually sentient, conscious and self-conscious states of being. (p. 117)

He adds that this storyline is a pregnant promise of things to come (even though the laws of thermodynamics eventually point to another direction). One may say that if natural selection does not require teleology, it does not and cannot rule out the possibility of intentionality (see Van den Brink 2017:270), at least among primates. This raises the question whether intentions played a role from the beginning (before sentient beings emerged) or only subsequent to the emergence of hominids. In other words: was God as Creator there long before humans emerged (the orthodox position) or did the notion of 'God' only emerge much later as a result of cultural evolution (the liberal position). Or is 'God' another (pantheist, panentheist or process) name for the 'wellspring of novelty' that 'abides in the depths of the universe (Haught 2000:9)? This debate remains unresolved and is picked up more recently in debates on the emergence of pro-sociality, morality and religion (see also below).

In the interim, scientific debates on the (exclusive?) role of natural selection in evolution continue unabated. One debate is on the appropriate unit for selection - genes (Dawkins), individual organisms (Darwin) or whole species (Gould). Another debate is on the tempo of evolution, that is, as a gradual process or with a punctuated equilibrium. There are also questions about the directionality of evolution: is the tendency towards increasing diversity and complexity (and beauty?) itself a product of chance or not? The most significant debate is perhaps on whether natural selection is the most significant (but not the only) driver of evolution - for example, alongside other naturalistic factors such as genetic assimilation, self-organisation and top-down causation (Peacocke 2001:24-25). As Jablonka and Lamb (2014) argue, variation can be transmitted through genetic, epigenetic, behavioural and symbolic inheritance, upon which natural selection can act. There are further debates on the role of niche construction in the evolution of species. Put cryptically, some argue that niche construction plays a role in natural selection, while others argue that natural selection plays a role in niche construction. It comes as no surprise that theologians are keenly observing such cutting-edge debates in evolutionary theory (see, e.g., Deane-Drummond 2014). Again, the theological debate on this remains unresolved.

\section{Human descent}

The evolutionary roots of human origins have been a point of controversy in Christian circles ever since Charles Darwin's early contributions, especially following The Descent of Man, 1871. The resistance against the notion of 
human descent from a lineage of mammals, great apes, hominids and hominins is clearly related to an emphasis on humans being created in the image of God. This forms the cornerstone of an understanding not only of human dignity but also of human dominion (or domination) over other species. One may assume that such resistance against the evolutionary roots of human descent is also related to cultural notions of civilisation - not only in Europe. To call another human an animal remains an insult in many contexts. Strangely, the same does not apply to calling humans a form of life (alongside plants, insects and amoeba). To speak of a 'living God' is taken for granted but nevertheless counterintuitive given that life assumes being embodied and therefore evolutionary descent.

Although this debate is far from being resolved in worshipping communities, human descent from the great apes is by now widely endorsed in scholarly circles. There are especially four reasons for this emerging consensus. Firstly, there is simply the weight of scientific evidence that is so overwhelming and (from a South African perspective) so intriguing that it seems foolish to argue against that. Secondly, theological attempts to locate the image of God in the human soul or to make absolute claims for human uniqueness have largely failed. There is a widespread theological, and not merely a secular, critique against anthropological dualism or tripartite divisions between body, soul and spirit. Thirdly, biblical exegesis and theological reflection alike have convinced many theologians that we human beings need to see ourselves as creatures, on the side of creation, and not only (as the image of God) as God's representative on Earth. There is a need to recognise a 'solidarity of the sixth day'. This, at least, is the message coming from almost all forms of Christian ecotheology. Finally, there is a strong argument to be made that human dignity and the integrity of God's creation are not inversely proportioned. To emphasise human dignity is to affirm the evolutionary lineage that made human descent possible. Human dignity is therefore a paradigm for affirming the goodness and preciousness of all of life. This is radicalised with the notion of deep incarnation: in Jesus God became animal, a form of life and in this way affirmed the whole evolutionary lineage of the human species (see Gregersen 2015).

Nevertheless, the scholarly debate on the significance of human origins is far from being resolved. This may be illustrated on two fronts.

Firstly, scientific debates on human uniqueness continue unabated. Most scholars, with animal ethologists, are at pains to stress continuity with other species typically on the basis of DNA comparisons, and also in terms of behavioural studies and brain functioning. Frans De Waal (2016:158) even calls for a moratorium on claims for human uniqueness given its miserable track record. There is ongoing debate on protoculture (rituals), proto-morality and even proto-religion. However, the emergence of consciousness, self-consciousness, human consciousness and symbolic communication still demands much scholarly interest. There can be no doubt about human distinctiveness (all specimens of all species are indeed distinctive). Claims for human uniqueness will necessarily be contested, but it is hard to avoid the weight of evidence on the amazing human ability to use symbols in communication (e.g. Deacon 1997, 2013). Arguably, it is this ability that has allowed for the emergence of complex human civilisations with its many constructive and destructive dimensions. Sometimes small mutations can be extended exponentially to make huge differences.

The recognition of such human uniqueness (see Van Huyssteen 2006), contested as it may be, calls for scientific, philosophical and theological interpretations alike. If complexity is the criterion and if human brains and therefore human societies are the most complex feature of the universe that we know of, then we are arguably back in a preCopernican world where the whole history of the universe seems to revolve around (better: culminate in) the emergence of such a species. This is the question that energises debates on the anthropic principle, a reconstruction of hominid evolution, philosophical theories of mind and legal debates on human dignity alike. In the destructive context of the Anthropocene, this leads to many further questions about anthropocentrism, using anthropomorphic categories, and about anthropogenic climate change. The fact of human descent from other hominids should no longer be contested, but its significance remains as elusive as ever.

Secondly, the recognition of human continuity with all other forms of life has not resolved a complex set of questions around human interaction with other plants and animals. There may be widespread consensus of the need for animal welfare, for the humane (?!) treatment of other animals and for wisdom in economic engagements within ecosystems (e.g. to resist folly in the overuse of pesticides). However, the need for human protection against predators and pests indicates that many issues remain unresolved. Why do most humans feel entitled to kill pests but not pets? Moreover, there are ongoing debates on the role of predation among animals and the human need to kill other forms of life for food (see Conradie 2016; Welker 2017). This is not only a debate on (more) vegetarian or vegan diets; vegetarians also uproot and absorb living organisms in order to sustain themselves (e.g. carrots, potatoes and cabbages). There are forms of food where killing life is not required (e.g. fruits, nuts and seeds), but few people would restrict themselves to such an Eden diet. One does not need to kill in order to consume eggs, milk, cheese and honey - but then it seems that some 'stealing' is required! Moreover, such rules on what may be eaten do not apply to other animals so that introducing that among humans implies some claim for human uniqueness.

Some form of hierarchy is almost inevitably introduced to defend eating patterns, for example, to explain why one may eat chickens but not children, or chick peas but not chickens. However, there is also much resistance against such hierarchical thinking, not least because this may become extrapolated within human communities. If value richness, 
rational capabilities or complexity is the criterion, why does this not apply among humans as well? This criterion is indeed applied among humans, for example, in terms of levels of education. However, how can the equal dignity of all human persons then still be defended (e.g. before the law), if not in terms of status in society (or in terms of remuneration on the basis of 'value' to the company). Either way, these reflections suggest that the significance of human descent from other forms of life has by no means been fully clarified neither in theological nor in secular discourse.

\section{Natural suffering}

Evolution through natural selection implies pain, suffering and anxiety, especially among those species with a complex enough nervous system to experience that. Such suffering comes in many forms. There is the biological inevitability, and indeed necessity, of death in multi-cellular organisms. This is aggravated by ageing and degeneration. There is also the always imminent fear of predation and the inevitability of becoming food for others. Then there is the anxiety of the weak, slow, fragile, old and not so clever, recognising the threat of non-selection, the fear of not being 'fit' enough to survive in an always competitive if not always hostile world. Then there is the recognition that applies to many species, namely, that only a few specimens will reach maturity and will be able to procreate - most others die young and become food for others. The main problem is not so much pain (a necessary concomitant of sentient life) or death (a thermodynamic necessity), or the loss of non-living entities (through change), but that many (or most, in some species the vast majority) living creatures seem to be the victims or casualties of evolution in the sense that they die prematurely so that their lives are all suffering and no richness or joy (Southgate 2008:40). Some would add evidence of the apparent brutality found among non-human animals against other species but also within a species (see Southgate 2008:ix). Such brutality is of course primarily found within the human species and in the interaction between humans and other animals, but there are obvious analogues among other species that are disturbing to many observers.

Although the prevalence of such natural suffering, that is, suffering not induced directly or indirectly by humans, was well recognised by early exponents of the theory of natural selection, the focus of theological attention was originally not much on this aspect of evolutionary theory. Humans may of course exacerbate such suffering but there would have been such suffering irrespective of the presence of humans in ecosystems. The underlying problem is that such natural suffering (that cannot be blamed upon humans) casts a dark shadow over the Jewish-Christian affirmation that the world that God created was 'quite good', indeed 'very good', if not perfect in a Platonic sense. Moreover, as Southgate (2008) acutely notes:

$[\ldots]$ the very processes by which the created world gives rise to the values of greater complexity, beauty, and diversity also give rise to the disvalues of predation, suffering, and violent and selfish behavior. (p. 29)
Death is not merely an unfortunate side-effect of evolutionary change but built into the very process of evolution (Edwards 2006:106). Extinction and evolution form part of the same 'package deal' (Gregersen 2001:201). This questions the goodness of the loving Creator. Is God not ultimately responsible for such suffering? If the suffering of creatures is necessary for evolution, are the victims of evolution the means to achieve some long-term divine purposes (Southgate 2008:9)? Do such ends justify the means? Put provocatively, how dare God declare what is so horrifying to be good?

In recent years there have been numerous theological attempts $^{8}$ to address the problem of natural suffering as part and parcel of evolutionary history, often under the rubric of revisiting the classic theodicy problem. Arguably, a similar range of 'solutions' to the theodicy problem is found in attempts to address such natural suffering. Some scholars argue that evolution through natural selection was the only conceivable way in which God could allow for the emergence of diversity, complexity and beauty (see Southgate 2008:29,48). The possibility and inevitability of natural suffering is a necessary condition required for the emergence of the human species. Suffering, disease, death and extinction are the price God was willing to 'pay' (because this was the only way) to 'purchase' the evolution of free agents with reciprocal love (Peters \& Hewlett 2003:155). In such a teleological scheme, the ends of God's encompassing plan therefore justify the means, but this is counter-balanced by the insistence that God shares in the world's suffering. In Arthur Peacocke's panentheistic model, suffering takes place within God so that creating is costly to God (2004:105). As Peacocke (1993:126) puts it, 'God suffers in, with and under the creative process of the world with their costly, open-ended unfolding in time'.

In response to the problem of natural suffering, many theologians emphasise the notion of kenosis and the vulnerability that love requires (see especially Polkinghorne 2001). They tend to welcome evolutionary insights on the role of natural suffering as this has helped Christian theology to recognise God's suffering love in a way that is often marginalised in theological discourse. Francisco Ayala (2007) and John Haught (2000:45-56) even speak in this regard of Darwin's 'gift' to theology. ${ }^{9}$ For Arthur Peacocke (2004) evolution is the 'disguised friend of faith' because it demands (in his view at least) a shift from deist or theist models to a panentheist understanding of God's presence in everything and the presence of all of life in the one in whom we live and move and have our being. The abstract Greek characteristics of a divine being (omniscience, omnipotence and omnipresence) dominated theological reflection for too

8.There are too many contributions in this regard to list here. Perhaps the most detailed discussion is offered in the volume edited by Murphy, Russell and Stoeger (2007).

9.See my earlier discussion (Conradie 2013a) of such an ambiguous 'gift', keeping in mind that 'gift' in Germanic languages also means 'poison'. The ambiguity lies in the danger that interesting intellectual inquiries on the theodicy problem can the danger that interesting intellectual inquiries on the theodicy problem can
divert attention away from the primary problem, namely, the destructive impact of divert attention
human sin. 
long but an appreciation for evolutionary history allows and indeed invites an appreciation for vulnerability, compassion and solidarity. The deadening disguise of order and design smothered a sense of the tragic aspects of divine creativity (Haught 2000:5). God's power is not of a physical, military, political, financial, intellectual or technological nature; it is the creative power of attraction and attachment, building relationships through communion. God operates through persuasive rather than coercive love. This power is necessarily slow and vulnerable, but in the long run the execution of one reformer on a cross has proved to be more transformative than the power of empires. This allows for an appreciation of the counter-intuitive nature of an affirmation of the goodness of creation: despite the prevalence of nature suffering, one may appreciate that what is earthly and bodily is nevertheless 'very good'. Indeed from God's perspective the world is so good, so beautiful and so precious that it is worth dying for. The cross of Jesus Christ is God's claim to this world, the claim of a lover yearning to love and be loved, not the claim of a despot yearning for power, control and glory (Hall 2003:37).

Such arguments are reiterated by a significant chorus of contemporary (Western) theologians coming from diverging theological traditions (if perhaps not yet dominant in liberation theology, Pentecostal theology or African theology). No one would dare to suggest that the theodicy problem has been resolved, but the emerging consensus on the significance of vulnerable love is so persuasive that the burden of proof is now on those who wish to defend a diverging position. There remain lingering questions on liberal or secular assumptions though: what is the difference between the divine restraint exercised by the Father in abandoning (or at least not rescuing) his beloved Son on the cross, an abusive parent, an impotent parent or no parent at all? A powerless God cannot redeem us. Alternatively, the sources of salvation have to come from within - in the sense of the regenerative powers of God's body being able to heal itself. This comes close to a Pelagian position where we have to save ourselves - and where we have to save the Earth from anthropogenic destruction too.

There are also differences of opinion about the ways in which such suffering love is exercised in God's work of creation, on the one hand, and God's work of redemption, on the other hand. In both cases, God takes creaturely pain to heart (Southgate 2014:805). However, whether creation is by itself, therefore cruciform remains a point of theological controversy as posing an underlying kenotic principle would undermine the historical contingency of the cross. ${ }^{10}$ The point that Christians would need to affirm about the cross is not merely that suffering and death is recognised.

10.One may find the emphasis on such a kenotic principle in the work of a wide array of contemporary Catholic and Protestant scholars, including Niels Gregersen, John Haught, Elizabeth Johnson, Sallie McFague, John Polkinghorne and Holmes Rolston II. Ellis and Murphy (1996) in recognising Joh kenosis III. Ellis and Murphy (1) nature of the universe'. However, the caution that kenosis in redemption is based conting sense historically is in is in my view rightly raised by others, including Denis Edwards (2006:108) and Christopher Southgate (see 2008:83). Kenosis is not an aim in itself; it has meaning only in order to restore broken relationships (see Edwards 1999:26).
Suffering from injustices (symbolised by the cross) is indeed recognised but then revealed in all its brutality, not blessed or condoned. This opens the possibility of God's work of redemption, renewal and transformation, symbolised by the resurrection (see Peters \& Howlett 2003:172). The question remains, though, whether the message of redemption is aimed primarily at the injustices, oppression and premature death that result from human sin, or at the suffering embedded in God's creation, or both (as many would agree too quickly). If the emphasis is on both natural evil and social evil, the tendency may be to conflate creation and fall so that God's work of redemption has to overcome the inadequacies of the work of God as Creator. To conflate creation and fall often yields a conflation of creation and salvation as well (e.g. with Teilhard or in process thinking) so that God's work of creation becomes salvific and God's work of salvation becomes creative. ${ }^{11}$ Alternatively, if natural evil and social evil become separated, the conversation with evolutionary biology is undermined (as is often the case outside of Western theology).

It may be interesting to explore how leading Western theologians who seek to recognise insights emerging from evolutionary biology, such as Celia Deane-Drummond, Denis Edwards, Philip Hefner, Niels Henrik Gregersen, John Haught, Elizabeth Johnson, Sallie McFague, Jürgen Moltmann, Arthur Peacocke, Ted Peters, Holmes Rolston, Robert John Russell, Christopher Southgate and others, have understood redemption in subtly diverging ways, either emphasising natural evil or social evil. My guess is that, lurking behind their positions, there remain deep confessional divides between the main branches of the Christian tradition on nature and grace.

The most significant theological differences emerge on the question whether such natural suffering will be overcome eschatologically. The question is whether we are to be redeemed from human sin only or also from death. If the latter is included, is that because death is the 'wage' of sin or the underlying cause of $\sin ?^{12}$ Who are to be included under this 'we': humans only (as the Western church often assumed), some humans only (prompted by Calvinist and millenarian debates on election and reprobation), or is the whole Earth,

11.I have argued elsewhere at some length why such a conflation of (ongoing) creation and salvation is not a viable route (see Conradie 2013c, 2015). In brief, it is neither clear what is being saved and where what is comes from, nor where the source of salvation has to come from.

12.Note that these questions allow for diverse positions on three axes: (1) ranging from the elect only, humans only, sentient beings only to the whole cosmos;
(2) views on how sin and death are related; and (3) whether redemption from (2) views on how sin and death are related; and (3) whether redemption from
social evil only or also from natural evil is plausible. See, for example, Elizabeth Johnson's discussion in Ask the Beasts (2014). She wants to retain not only the Western focus on being redeemed from sin, but also the Eastern openness to the cosmic scope of redemption and the hope to be delivered from death and its corruption (p. 224). God created all things and will redeem all things (p. 228). She rightly focuses on the interplay between cross and resurrection, and this enables her to affirm that grace entails liberation from sin and death (p. 225), not least because 'the death of Jesus is indissolubly connected with $\sin ^{\prime}$ (p. 226). How that 'and' is to be interpreted is another matter, as Johnson clearly affirms that death is inextricably linked to creaturely finitude: we suffer and die (pp. 181-186). If so, is inextricably linked to creaturely finitude: we suffer and die ( $\mathrm{pp}$. 181-186). If so, why do we need to be redeemed from death? Is this not a refusal to accept life on the Creator's terms? Or is destruction, death and extinction indeed the ecological wage of $\sin$ (pp. 241-253)? Johnson finds her way out of the entanglement through a Catholic notion on grace elevating nature, the Orthodox notion of theosis and the Scotist position that the incarnation would have taken place whether human beings have sinned or not (p. 226). Clearly the old confessional divides on nature and grace continue to influence debates on evolution. 
indeed the entire cosmos to be redeemed (as Moltmann and others would insist)? If the latter, how is such an eschatological victory over death to be imagined in light of evolutionary history? Will the suffering embedded in evolution somehow be overcome by a radically new creation of all things? Some look for signs from within an unfinished, evolving creation pointing towards a reduction of suffering - but then tend to sacrifice the victims of evolutionary history through some teleological scheme, that is, for the sake of some future dispensation. Others refer to the dialectic between cross and resurrection to express the hope that all suffering of all creatures will be removed eschatologically. Yet others think in terms of dialectic materialism, a process metaphysics of the future (Haught 2000:83-93), or a proleptic eschatology. Such long-standing debates on eschatological consummation remain unresolved, ${ }^{13}$ but are not initiated, only intensified by insights emerging from evolutionary biology.

That the theodicy problem remains very far from resolved is also indicated by the next two questions that have to be addressed once such a theological position on God's vulnerable love is adopted.

\section{The evolutionary roots of evil?}

The recognition that suffering among sentient animals is something natural, that it is not necessarily induced by humans or the result of human sin, but that it may well be exacerbated through human involvement, cannot be denied in any theological discourse on evolution. Such natural suffering is sometimes described as 'natural evil' to capture the origins of such suffering (see Drees 2003; $\mathrm{Du}$ Toit 2006). As the term is introduced to distinguish natural evil from social evil and thus to acknowledge nonhuman origins of suffering, it seems to me that 'evil' is a misnomer to describe what is (or seems to be) 'bad' or disadvantageous for an organism. There are no evil intentions or evil-mindedness at stake, unless these can be ascribed to angelic or divine forces, which deserve no further comment besides ongoing debates on the plausibility of a cosmic fall (see Van den Brink 2017:153-162).

This does not imply that the relationship between natural suffering and social evil has been resolved, far from it. The question remains whether such suffering, the role of predation and the anxiety experienced may provide some explanation for the origins of social evil. This is suggested by the many behavioural continuities between other primates and humans. As Domning and Hellwig (2006) observed:

it is empirically apparent that the human behavior patterns denoted by our words 'murder', 'theft', 'deceit', 'possessiveness', et cetera, are not (as traditionally assumed) uniquely the property of humans, nor are these resemblances to other species likely to

13.As I have argued elsewhere (Conradie 2015:272-287), there are divergin theological positions here that can be classified in terms of key words such as reological positions restoration (the classic reformed position), elevation (the classic Catholic and Eastern Orthodox position), replacement (the Anabaptist option) or endless recycling (a libractions Aned, but as far as I can see the (perhaps Anglican) emphasis on creation (as kenotic or cruciform) or incarnation (God's suffering with creatures) alone would not do either - as this leaves those who suffer (and will die suffering) without hope. be coincidental (resulting from the independent 'invention' by different species). Instead, we may infer that these traits of ours are shared with other species precisely because the common ancestor of all these species possessed them. (p. 105)

The underlying problem is that humans share traits with other animals that would be regarded as 'sinful' if done by humans. This raises the question whether only humans sin (see Conradie 2017a)?

However, to suggest that social evil is the 'necessary' result of human evolution would undermine human responsibility, moral education, legal accountability and policy-making. Humans are not merely evolutionary victims of their own genes, but remain responsible for what has gone wrong (see Van den Brink 2017:259-260). But could sin be regarded as the more or less 'inevitable' outcome of human fragility? Edward Farley (1990:29, 121), for example, carefully locates the origin of sin against the 'motivating background' of the tragic character of human existence, that is, the striving to survive and to seek the conditions of well-being amidst limitations, vulnerabilities and biologically rooted challenges that are rooted in our phylogenetic make-up.

Where, then, does evil ultimately come from? This is not a problem that can be ignored if indeed evil is largely a problem for victims rather than for perpetrators and given the temptation for scapegoating. The pertinent theological question is how both monism (making a 'darker' side within God responsible for evil) and dualism (allowing for evil that is co-original with God) can be avoided in addressing the origin of evil? ${ }^{14}$

In the biblical roots of Christianity, there is an overwhelming recognition (a biblical apriori according to Berkouwer 1971) that God 'abhors' sin so that monist views are unattractive. This would make God the ultimate cause of evil, the author of sin. That also applies to one standard answer from the Christian tradition, namely, that God did not will sin, but permitted it and did not prevent it. If God created humans as free beings and thus allowed sin, is God not still ultimately responsible for sin? Is being willing to allow something any better than willing it? Nevertheless, monism is not that easy to avoid because, as Herman Bavinck (2006:56) maintained, a power as appalling as sin could hardly have arisen accidently, apart from God's will and counsel. Elsewhere Bavinck (2006:182) is bold enough to say this: 'For God the fall was neither a surprise nor a disappointment. He anticipated it, incorporated it into his counsel, and already took account of it in creating the world'. This leaves an unresolved Augustinian paradox: what is done against God's will is not done outside of God's will. If so, God willed at least the possibility of sin.

14.The debate on the origins of human sin is often confused and conflated with discourse on original sin, which in my view is best understood in terms of the planetary spread and inescapability of sin. It has more to do with the consequences than with the origins of sin. It describes the situation in which one finds oneself and that has preceded oneself. For a notion of original sin as explanatory ground for the origins of sin, see Domning and Hellwig (2006), Haught (2000:137-143), for the origins of sin, see Domning and Hellwig (2006), Haught (2000:137-143),
Hefner (1993:123-142), Peterson 2004, Suchocki (1994) and Williams (2001). For a different view, see Edwards (1999:64-70, 2010:129-142). For secular explorations of the notion of original sin, see Boyce (2015) and Jacobs (2008). See also my of the notion of original sin, see Boyce (2015) and Jacobs (2008). See also my
critical engagement with Haught's position (Conradie 2016) and the discussion in Redeeming Sin? (Conradie 2017b:131-142). 
More recently, Christopher Southgate (2014) has been willing to confront such dangers of monism in his evolutionary theodicy by refusing to let God off the hook for creaturely suffering. His notion of the glory of God is at once aweinspiring and ominous. One may then extend the argument to include God's responsibility for the emergence of sin. If human fallenness is a necessary or inevitable function of human evolution, then salvation in Jesus Christ has to address not only human fallenness but also the underlying problem that gave rise to such fallenness.

Dualist positions suggest that there is an underlying form of evil in the world that is often associated with that which is material, bodily and earthly, often with female embodiment (Eve) or with bodily passions. Accordingly, sin may be regarded as the necessary by-product of bodily existence or human sexuality. In radical feminism, this is reversed so that a spurious parasitic maleness, feeding off women as creative life bearers, is regarded as the source of evil (Ruether 1992:148). The sources of evil may also be located in the forces of chaos, darkness, formlessness, vacuity (Moltmann 1985), the so-called 'shadow side' of being a finite creature, or nothingness, that which God did not will (Barth's Das Nichtige) - which would make evil metaphysically necessary. God's act of creation may then be regarded as a victory over the forces of chaos and destruction. And also of male rationality over female emotivity? Alternatively, the origins of evil may be found in the figure of Satan (a fallen angel?) as God's opponent.

However, any sustained form of dualism would undermine God's sovereignty, suggesting that there is something outside of God's control. The problem is not only that this would be blasphemous but also that it leaves the victims of history without hope. If sin is not God's will, it at least does not go beyond God. God can use sin and invert it for salvific purposes - as demonstrated in the horrifying execution through the cross. Likewise, chaos does not lie outside God's freedom and may be used by God for creative purposes, even to play with (Van Ruler 2009:159-172).

As John Hick (1966:286) already recognised, the problem is that sin is either rendered impossible by the created perfection of human beings (implying their presumed original righteousness) or else is so very possible that it is excusable. $\mathrm{Sin}$ is thus made more or less inevitable by the recognition of some inherent flaw that renders us vulnerable to temptation (which again makes God responsible for sin). Moreover, if sin is truly inexplicable, must it be understood as a form of selfcreation ex nihilo in the midst of a wholly good world created by God? Does monism not then revert to dualism? As Robert Williams (1985) observed:

The classic doctrine is impaled on the first horn of the dilemma (original righteousness excludes sin), while modern theological reconstructions are confronted with the other (to acknowledge a flaw seems to equate finitude with sin). (p. 209)

To put it mildly, this theological debate on the implications of evolution remains far from resolved. In the interim debates in sociobiology, evolutionary psychology and animal ethology on the interplay between competition and cooperation in the emergence of pro-sociality, proto-morality and human morality continue unabated.

As I have argued elsewhere (Conradie 2017b; Ricoeur 1967), it may be helpful to clarify the distinct narrative or mythic frameworks within which the story is told of what went wrong in evolutionary history to eventually produce the social evil that we find in the world around us. In the circles of evolutionary biology, sociobiology and evolutionary psychology, there is an underlying Manichaean vision where good and evil, survival and predation, conflict and cooperation are indeed more or less co-original. For some the moral of such a Manichaean version of the story is to accept the social Darwinian emphasis on the survival of the fittest. Others suggest that we need to muster the forces of goodness, if necessary to rebel against our own genes (Dawkins ${ }^{15}$ ), to sign a social contract to prevent an underlying conflict to have the last word. We have to save ourselves and we need to save the earth from ourselves. Or else we need to offer Stoic resistance given the recognition of an underlying tragic dimension to life (and death). ${ }^{16}$

Such a moral of the story may be more plausible in terms of evolutionary history, but is also less palatable for the victims of that history. Although some theologians are drawn to a vision of the tragic as a response to the theodicy problem, most shy away from such a Manichaean version of the story. However, they are also not attracted to the classic Augustinian position that sin is best understood as privatio boni. This narrative framework rejects both dualist explanations of evil (a rival power as the cause of sin - which undermines God's sovereignty) and monist explanations of evil (which renders God ultimately responsible for human sin). However, to insist that the good is primary and evil a privation of the good seems less plausible in light of evolutionary history. Southgate, for example, insists that evil is not a privation of the good, but a necessary concomitant of the creation of the good: 'the same processes that lead to the refinement of creaturely characteristics also lead to suffering and extinction' (Southgate 2015:247). This prompts Southgate to 'drop the fall' (Southgate 2008:28-35; Williams 2001). ${ }^{17}$ Celia DeaneDrummond (2009:187) does not wish to drop the fall but

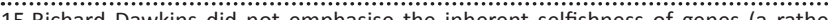
anthropomorphic metaphor) in order to justify such selfishness but to alert us of the need to overcome that. This becomes possible through our unique capacity for foresight that gives us:

the power to defy the selfish genes of our birth and, if necessary, the selfish memes of our indoctrination. ... We, alone on earth, can rebel against the tyranny of the selfish replicators. (Dawkins 2006:200-201)

Dawkins' notion of selfishness is strictly speaking amoral and refers to the drive of each gene to promote its own reproductive success. His argument is not that people spread their genes selfishly; genes selfishly spread themselves. However, it is not clear how one can adopt such a technical definition of selfishness by discarding its everyday meaning (assuming moral agents) without sacrificing conceptual clarity.

16.I note in passing how far this is removed from a Calvinist ethos based on the privation of the good leading to pervasive depravity - to be overcome only through God's grace leading to a sense of gratitude and a commitment to justice.

17. Besides several theologians who resist the notion of the fall as incompatible with human evolution, there have been some innovative attempts to offer a constructive
reinterpretation of the fall that takes hominid, hominin and human evolution into account. See, for example, Smith (2017) and Van den Brink (2017:228-242). 
nevertheless suggests that human fallenness is a 'culmination of tendencies already latent in the natural world'. How, then, should the evolution of $\sin$ be understood (see DeaneDrummond 2009:160-170)?

There is another option favoured by many theologians seeking to ensure compatibility with evolutionary history, namely, within an Irenaean narrative framework that emphasises a development path from innocence to maturity. This position is neatly captured by Arthur Peacocke (2004):

Human beings seem to be 'rising beasts' rather than 'fallen angels'. There is no evidence for a past paradisal, fully integrated, harmonious virtual existence of Homo sapiens, so how should this shape our understanding of the 'work of Christ' as 'redemption'? Should we not now be regarding the 'work of Christ' less as the restoration of a past state of perfection than as the transformation into a new as-yet-unrealized state? How did and does the life, death and claimed resurrection of Jesus make any difference? (pp. 179-180)

In Redeeming Sin? I argued that such an Irenaean framework can still be interpreted in diverging ways so that this debate too remains unresolved (Conradie 2017b). I also warned against conflating creation and fall by treating these as cooriginal, if not as alternating features of the human condition. For the victims of history, it remains necessary to make a distinction between creation and fall in order to maintain that 'this is not the way it's supposed to be' (Plantinga 1995).

\section{(S)election and the survival of the fittest}

In scholarly discourses on evolution, it is widely recognised that the phrase 'survival of the fittest' was introduced by Herbert Spencer although it was adopted by Darwin in the fifth edition of Darwin's On the Origin of Species. Given the association with social Darwinism, eugenetics, Nazi ideologies and support from early capitalists, the phrase 'survival of the fittest' is widely discredited in theological discourse (see Peters \& Hewlett 2003:51-69).

The phrase is also questioned for accuracy in biological debates on evolution. Many would argue that the basic flaw is associated with the focus on individual specimens who are supposed to be the 'fittest' and therefore able to survive long enough to procreate. Instead, the emphasis should be on the best adapted within a specific environment. In addition, an emphasis on niche construction allows for an adaptation of the environment and not merely adaptation to environmental changes. Survival is also not the only aspect of natural selection as survival without procreation would be futile in evolutionary terms. Moreover, many sociobiologists emphasise the role of cooperation rather than competitiveness (e.g. Nowak \& Highfield 2011). Those who work together and hang together have a much better chance of survival. This applies especially to social species, and most notably among humans where children remain dependent on others for many years before they can procreate. However, cooperation can serve diverging purposes - from raising children (Hrdy 2009) to waging war (see Fuentes 2017). One may conclude that natural selection is not best understood as a 'struggle' for the survival of the 'fittest'. As noted by Arthur Peacocke (2001):

Natural selection involves many factors that include better integration with the ecological environment, more efficient utilization of available food, better care of the young, more cooperative social organization - and better capacity of surviving such 'struggles' as do occur (remembering that it is in the interest of any predator that its prey survive as a species!). (p. 36)

These qualifications are widely welcomed in theological discourse. However, the bottom line of natural selection on the basis of fitness within a particular environment in order to survive and procreate remains in force as an assumption in biological theories of evolution. This recognition is aggravated by the role of variation and subsequent mutations. Some mutations may be beneficial, but most are harmful and only beneficial once it becomes incorporated in organisms through natural selection (Ayala 2007:77). The rest of the 'experiment' is simply discarded. Those specimens that cannot 'adapt' die and become food for others. This allows for the evolution of species over the longer term. I think it is fair to state that theologians have found it hard to come to terms with this biological bottom line. As Lisa Sideris (2003:45-90) has argued, many (feminist) ethicists who have embraced evolutionary insights have underplayed the fierce struggle for survival in evolutionary history.

The underlying problem is seldom stated in such terms, but one could raise the question as to how natural selection relates to divine election. The implied wordplay may be facile, but this at least raises the question whether natural selection is indeed a matter of selecting. This is clearly an anthromorphic term as there is no conscious selection at stake; it is more a matter of being eliminated because of failed adaptation. However, at least for the second pelican chick it is a matter of not being 'selected' by the mother bird (impure to eat according to Leviticus 11:18, associated with doom and destruction in Psalms 102:7, Isaiah 34:11, Zephaniah 2:14). The problem lies deeper than personifying nature though. In the biblical roots of the Christian tradition, there is overwhelming evidence that God responds to the cries of the weak and vulnerable, the outcasts and marginalised, the oppressed slaves rather than their oppressive slave masters, the colonised rather than the colonisers. This is of course open to theological interpretation, but the agenda is unmistakably set by liberation theology, black theology, Kairos theology, feminist theology, Minjung theology, Dalit theology and a variety of indigenous theologies. God is like a hen gathering her chickens (Mt 23:37), albeit not like a pelican hen! This poses an intractable theological problem: is God's work of salvation moving in a different direction compared to God's work of (ongoing) creation through evolution on the basis of natural selection (see Conradie 2013c, 2015)? Does this not lead us back to Marcion where God as Saviour has to bring some correction to the botched job of God as Creator? 
There are different avenues available for a theological response to this problem, but none of these seems to be satisfactory (at least in my view). One (somewhat secular?) option is to regard eating not as the killing of individual organisms but a transfer of energy through absorption and excretion to support the flourishing of the whole ecosystem. One may even welcome becoming food for others as a radical form of kenosis (see McFague 2013), but this option is hardly commendable and seems to come at the cost of the command to 'be fruitful and multiply'.

Another option is to admit that God is on the side strong after all, at least among non-human animals. This may sound heretical to many, but what sense would one make otherwise of spontaneous miscarriages (about $20 \%$ of pregnancies)? If one can find God's providential hand in allowing only those foetuses that are viable to survive, would that make God the greatest abortionist of all (Ayala 2007:157)? Or would one want to see all of them survive in the name of a God coming up for the discarded?

Another (perhaps Lutheran) solution may be to suggest that God takes the costs of evolution to heart through the incarnation and cross of Jesus Christ. This suggests a God who suffers with us in our weakness. It is not a God who blesses the survival of the fittest; through the cross God identifies with the unfit, with those who do not survive. This identification with the unfit unlocks the door to true life in communion with God (see Peters \& Hewlett 2003:141). If so, the cross is regarded as a response to the costs of creation (the Father's work) and not so much to human sin so that God's work of creation and redemption again stand in tension with each other.

Alternatively, one may hope for an eschatological resolution of the problem of premature death by offering solace to the victims of history (human and non-human) in a final victory over death, in a radically new creation where suffering will be no more. This (perhaps Anabaptist) solution is followed by many scholars aware of the costs of evolution: 'death as a characteristic of frail, temporal creation ... will be overcome through the new creation of all things for eternal life' (Moltmann 1996:78).

One may also argue that creation is God's ongoing project that remains experimental, open to trial and error, and incomplete. The evolution of life through natural selection was the only way in which God could allow for the emergence of life and for complex forms of life. God the Saviour engages with the work (creatura) of God the Creator in such a way that nature is in the long run ever more profoundly transformed by grace. This (Anglican and Catholic) position is perhaps the dominant one in contemporary debates. However, such a position on nature and grace cannot be taken for granted given deep confessional differences in this regard (nature and grace vs. sin and grace)..$^{18}$

18.This is of course the subject of long-standing debates, not least the one between Emil Brunner (2002) and Karl Bart (2002). In Dutch reformed theologis, this is (2002). In Dutch reformed theologies, also widely discussed. One of the most perceptive discussions is offered by Veenhof (2006) with reference to the work of Bavinck. See also my discussion of Bavinck's position on creation and salvation in Saving the Earth? (Conradie 2013c:77-120).
A final option is to question the role of natural selection in biological evolution, for example, by arguing that natural selection is not the primary driver of biological or cultural evolution or that the term as used by biologists is reductionist. This last option may obviously undermine a dialogue between evolutionary biology and Christian theology although a reminder may be appropriate that words such as adaptation, cooperation, competition, survival and selection are metaphors employed by biologists that can easily become ossified (see Haught 2000:90).

My sense is that theologians have typically failed to grapple with this obvious problem posed by evolutionary biology and, in an extreme form, by social Darwinism. This may simply be because divine election and natural selection are seldom placed in juxtaposition (see Kuyper 1998:412; Van den Brink 2017:238 though). Nevertheless, this clearly goes to the heart of the challenge posed by evolutionary biology to Christian theology, namely, to reflect on the identity and character of the God that Christians confess to trust. The facile response is that God loves all creatures, therefore comes up for the downtrodden and discarded against the strong and domineering, and will in the end establish victory over all suffering for all (sentient) creatures. Would one expect such a God create and sustain life through the mechanism of natural selection though? Faith in this God remains deeply counter-intuitive and, for many, offensive, either because this God is too weak or too strong. Nietzsche, for one, recognised this challenge better than most others. In often cited words, the biologist David Hull formulates the challenge starkly (quoted, e.g., in Ayala 2001):

What kind of God can one infer from the sort of phenomena epitomized by the species on Darwin's Galápagos Islands? The evolutionary process is rife with happenstance, contingency, incredible waste, death, pain and horror. ... Whatever the God implied by evolutionary theory and the data of natural selection may be like, he is not the Protestant God of waste not, want not. He is now even the awful God pictured in the book of Job. The God of the Galápagos is careless, indifferent, almost diabolical. $\mathrm{He}$ is certainly not the sort of God to whom anyone would be inclined to pray. (pp. 158-159)

In brief, who are (s)elected by the triune God? If Christians confess that God cares for the weak, how does that relate to the Darwinian struggle for survival? Is caring for the weak, poor and oppressed merely a requisite corrective to guard against the excesses of the strong? Or is God's care for the weak the heart of the Christian faith - as suggested by the notion of the preferential option for the poor in liberation theology and by a concern for God's justice in the Confession of Belhar? On this question there remain deep ecumenical divides, with some preferring a vulnerable God and others a God who can break the force of demonic powers. Many would want a God who is persuasive rather than coercive, but an impotent God simply cannot liberate 'us', whoever may be included under that. Instead God's power has to be understood in the context of living relationships (see Edwards 1999:42). 


\section{Natural selection as explanation for morality and religion}

A last challenge posed by evolutionary biology to an understanding of the Christian faith concerns the use of natural selection to account for the emergence of morality and religion. As mentioned above, attempts to derive a particular ethic from theories of evolution in terms of the notion of 'the survival of the fittest' have been widely discredited. Four main criticisms have been raised: (1) that the survival of the fittest is biologically inaccurate (given the role of cooperation among social species); (2) that cultural factors play a role in human communities alongside biological factors although biology allegedly holds culture on a 'leash' (Wilson 1978:167) - so that purely biological accounts of morality remain reductionist $\mathrm{t}^{19}$; (3) that this particular ethos is discredited given its social applications in eugenetics, Nazi ideology and unbridled capitalism; and (4) that this is a prime example of falling into the trap of the naturalistic fallacy by deriving an 'ought' from an 'is'. It seems clear that conflicting moral prescriptions have been and could be derived from animal ethology or evolutionary thinking - in support of capitalism (the role of competition), Marxism (class struggle), militarism (the fittest survive), socialism (the need for cooperation among social species), environmentalism (the resilience of ecosystems), anarchism (a natural inclination towards cooperation) and fascism (eliminating the weak) (see Ruse 2006:204-207).

One may conclude that the content of human morality cannot be derived merely from evolutionary biology as human behaviour cannot be reduced to genetic predispositions. However, there is another dimension of the debate, namely, with reference to attempts to offer an explanation for the emergence of morality and of religion in terms of evolutionary theory in general and natural selection in particular (for a survey, see Van den Brink 2017:290-324). If morality and religion may be found throughout all human communities and in diverse cultures, it seems mandatory to explain what the adaptive value of such features was in helping some communities to survive better than others. There is a growing corpus of literature that situates the emergence of morality in hominin history with the tacit assumption that such morality needs to be compatible with the role of natural selection (e.g. Joyce 2006; Ridley 1996). In studies on animal ethology, the development of forms of proto-morality among mammals, and especially primates, has been widely discussed in terms of capabilities for cooperation, empathy, compassion, comforting and peace-making (see, e.g., Bekoff \& Pierce 2009; De Waal 1996; Hrdy 2009; Spikins 2015). In the context of sociobiology and evolutionary psychology, the compatibility of an emerging sense of altruism with the role of 'selfish genes' (Richard Dawkins) prompted lively discussions. Such debates have been of interest to Christian ethicists

19. For a critique of this notion of a leash and a discussion of genetic determinants in culture, see Rolston (1999:120-140). He argues that natural selection is relaxed at the level of culture so that there is in the end no leash at all (which seems to go too far). If selfishness and self-assertion are appropriate, the emergence of culture and far). If selfishness and self-assertion are appropriate, the emergence of culture and
religion allows for values to be deliberately distributed, dispersed, allocated, religion allows for values to be deliberately distributed, dispersed,
proliferated, divided, multiplied, recycled and shared (see 1999:334). (see Deane-Drummond 2009:66-94; Messer 2007), but my understanding is that this does not by itself pose any serious challenges to an understanding of the Christian faith. There is no need to deny that human morality has to be anchored in mammalian sociality. ${ }^{20}$ Clearly, a sense of morality must have evolutionary roots.

The one exception may be where reductionionist assumptions are maintained in the sense that human morality can be fully explained in biological categories, thus underplaying the role of complexity that emerges through layers of information, enabling through complex feedback loops human freedom. At worst, ethics becomes nothing but a function of selfish genes. ${ }^{21}$ In human communities natural selection does not determine everything; there are indeed cultural memes (Richard Dawkins) that can be replicated elsewhere, but natural selection is hardly the best way to account for processes of social transformation. Such reductionism is widely criticised in Christian theology, but such critique is also found in other disciplines in the humanities and social sciences. There is indeed some lively debate on the interplay between selfinterest, conflict, cooperation, empathy, reciprocity, altruism and love.

Similarly, there have been several attempts to explain the emergence of religion and proto-religion in terms of theories of natural selection (see also Du Toit 2009). What has been the adaptive value that religion added to human communities which enabled them to survive better in an otherwise hostile world where there is competition for resources? Is religion an evolutionary useless by-product or perhaps a useful adaptation to support cohesiveness and cooperation in human communities (following Durkheim)? This question is often addressed with atheist assumptions, that is, without any reference to the possibility of divine revelation (see Van den Brink 2017:301, 312-324). This is often correlated with a discussion of secularisation, namely, to explain why religion is no longer necessary as, arguably, it has little adaptive value in modern, industrialised societies.

Again, my understanding is that this debate does not by itself pose grave challenges to Christian theology on the basis of evolutionary biology. Christian theologians may well appreciate any historical studies that can illuminate the emergence of religion. Likewise, they may appreciate studies conducted in the field of the cognitive science of religion that

20.0 Waal $(2006 \cdot 167-170)$ describes the evolution of morality in terms of three levels. The upper levels cannot exist without the lower levels. The first level is the role of moral sentiments (empathy, reciprocity, retribution, conflict resolution for role of moral sentiments (empathy, reciprocity, retribution, conflict resolution for
the sake of harmonious relationships and a sense of fairness) that are continuous with primate sociality. The second level is constituted by the social pressure put onto every member of the community to contribute to common goals and uphold agreed-upon social rules. Amongst primates such social pressures are closely related to immediate consequences for the community, but amongst humans this is extended much further to include social status associated with contributions beyond the immediate community. The third level is governed by moral judgements and moral reasoning - where comparisons with other animals become scarce. Here we evaluate the intentions and implied beliefs of others and seek an internally Here we evaluate the intentions and implied beliefs of others and seek an internally consistent moral framework. De Waal believes that the level of abstraction and self-reflection that this entails is a uniquely human feature. Nevertheless, the social tendencies. Social interaction remains at the root of moral reasoning.

21.See the infamous comment by Michael Ruse and Edward O. Wilson (1985:50): 'Morality, or more strictly, our belief in morality, is merely an adaptation put in place to further reproductive ends'. 
seek to understand the cognitive processes involved in religious practices and the emergence of such capabilities. There are lively debates here, but this is a debate on atheist and/or reductionist assumptions rather than on human evolution or on the role of natural selection. To locate a Godgene would help little to prove or disprove the viability of religion and even less to undermine the plausibility of the Christian trust in a triune God. In the same way that processes of cultural evolution cannot be derived merely from biological evolution, the evolving Christian understanding of God cannot be derived merely from the emergence and evolution of religion. Christianity is one form of religion, but the critique of idolatry (the theological critique of forms of Christianity) suggests that its understanding of God is not merely one such notion of the divine alongside many others. The question is not whether a notion of God emerged but which one. The whole history of the Jewish-ChristianMuslim tradition entails a debate on this question.

A distinction thus needs to be made between evolutionary theory (on the basis of biological evidence) and the metaphysical assumptions that some theorists employ to explain the significance of such theory (often dubbed as evolutionism - see Van den Brink 2017:30). In other words, this is a debate on worldviews and/or metaphysical assumptions, not on evolutionary biology by itself. To offer an explanation of the origins of morality and religion is not yet to offer an adequate justification for any particular form of morality or of religion (or of its absence). That is best regarded as the terrain of philosophy and theology (see Van den Brink 2017:318).

Scholars who opt for a confrontational model of the relationship between evolutionary biology and Christian theology typically fail to heed such a distinction. This applies to creationists and militant atheists alike. This can only lead to confusion. Once such a distinction is acknowledged, the confrontational debates can arguably be resolved. However, the philosophical debate on the metaphysical assumptions of theories of natural selection is clearly not resolved, neither are ethical debates on the implications of natural selection (e.g. for human relations with other animals) or Christian theological debates on God's identity and character in relation with other religious traditions.

\section{Conclusion}

A very brief conclusion may suffice. This article outlines the status questionis on the challenges posed by evolutionary biology to an understanding of the plausibility of the Christian faith. My argument has been that different layers can be identified in the evolving debate, that there is an emerging consensus on some aspects of the debate (outside the circles of creationism), and that in each case there are underlying problems that remain very far from being resolved. It may, at times, be helpful to outline an agenda for further deliberation, with the recognition that any such agenda will itself become contested quite rapidly.

\section{Acknowledgements Competing interests}

I declare that there are no competing interests that has influenced me in writing this article.

\section{References}

Ayala, F.J., 2007, Darwin's gift to science and religion, Joseph Henry Press, Washington, DC. Barth, K., 2002, 'No! an answer to Emil Brunner', in K. Barth \& E. Brunner (eds.), Natural theology, pp. 67-128, Wipf \& Stock, Eugene, OR.

Bavinck, H., 2006, Reformed dogmatics, volume 3: Sin and Salvation in Christ, J. Bolt (ed.), Baker Academic, Grand Rapids, MI.

Bekoff, M. \& Pierce, J., 2009, Wild justice: The moral lives of animals, University of Chicago Press, Chicago, IL.

Berkouwer, G.C., 1971, Sin, Eerdmans, Grand Rapids, MI.

Boyce, J., 2015, Born bad: Original sin and the making of the Western World, Counterpoint, Berkeley, CA.

Brunner, E., 2002, 'Nature and grace: A contribution to the discussion with Karl Barth', in K. Barth \& E. Brunner, Natural theology, pp. 15-64, Wipf \& Stock, Eugene, OR.

Conradie, E.M., 2010, Lewend en kragtig? In gesprek oor God se handelinge in die wêreld, Bible Media, Wellington.

Conradie, E.M., 2013a, 'Darwin's ambiguous gift to reformed theology: The problem of natural suffering and Calvin's meditation on future life', in H. Van der Belt (ed.) Restoration through redemption: John Calvin revisited, studies in reformed theology 23, pp. 95-112, Brill, Leiden.

Conradie, E.M., 2013b, 'The God of life: A counter-intuitive confession', The Ecumenical Review 65(1), 3-16.

Conradie, E.M., 2013c, Saving the Earth? The legacy of reformed views on 'Re-creation', LIT Verlag, Berlin.

Conradie, E.M., 2015, The Earth in God's Economy: Creation, Salvation and Consummation in Ecological perspective, LIT Verlag, Berlin.

Conradie, E.M., 2016, 'What do we do when we eat? Part 1: An inconclusive inquiry', Scriptura 115, 1-17.

Conradie, E.M., 2017a, 'Do only humans sin? In Conversation with Frans de Waal', in M. Fuller \& D. Evers (eds.), Are we special? Science and theology questioning human uniqueness, pp. 117-135, Springer, Heidelberg.

Conradie, E.M., 2017b, Redeeming sin? Social diagnostics amid ecological destruction, Books Lanham, Lexington.

Dawkins, R., 1996, The blind watchmaker, W.W. Norton, New York.

Dawkins, R., 2006, The selfish gene, Oxford University Press, Oxford.

Deacon, T.W., 1997, The symbolic species: The co-evolution of language and the brain, W.W. Norton, New York.

Deacon, T.W., 2013, Incomplete nature: How mind emerged from matter, W.W. Norton, New York.

Deane-Drummond, C.E., 2009, Christ and evolution: Wisdom and wonder, Fortress, Minneapolis, MN.

Deane-Drummond, C.E., 2014, The wisdom of the liminal: Evolution and other animals in human becoming, Eerdmans, Grand Rapids, MI.

De Waal, F.B.M., 1996, Good natured: The origins of right and wrong in humans and other animals, Harvard University Press, Cambridge, MA.

De Waal, F.B.M., 2006, Primates and philosophers: How morality evolved, Princeton University Press, Princeton, NJ.

De Waal, F.B.M., 2016, Are we smart enough to know how smart animals are? W.W. Norton, New York.

Domning, D.P. \& Hellwig, M.K., 2006, Original selfishness: Original sin and evil in the light of evolution, Ashgate, Aldershot

Drees, W.B. (ed.), 2003, Is nature ever evil? Religion, science and value, Routledge, London.

Du Toit, C.W. (ed.), 2006, Can nature be evil or evil natural? A science and religion view on suffering and evil, RITR, Pretoria.

Du Toit, C.W. (ed.) 2009, The evolutionary roots of religion: Cultivate, mutate or eliminate? RITR, Pretoria.

Edwards, D., 1999, The God of evolution: A Trinitarian theology, Paulist Press, New York.

Edwards, D., 2006, 'Every sparrow that falls to the ground: The cost of evolution and the Christ-Event', Ecotheology 11(1), 103-123. https://doi.org/10.1558/ecot.2006. 11.1.103

Edwards, D., 2010, How God acts: Creation, redemption, and special divine action, Fortress, Minneapolis, MN

Ellis, G.F.R. \& Murphy, N., 1996, On the moral nature of the universe: Cosmology, theology, and ethics, Fortress, Minneapolis, MN.

Farley, E., 1990, Good and evil: Interpreting a human condition, Fortress, Minneapolis, MN.

Fuentes, A., 2017, The creative spark: How imagination made humans exceptional, Penguin, New York. 
Gandolfo, E.O., 2015, The power and vulnerability of love: A theological anthropology, Fortress, Minneapolis, MN.

Gregersen, N.H., 2001, 'The cross of Christ in an evolutionary world', Dialog: A Journal of Theology 40(3), 192-207. https://doi.org/10.1111/0012-2033.00075

Gregersen, N.H. (ed.), 2015, Incarnation: On the scope and depth of Christology Fortress, Minneapolis, MN.

Hall, D.J., 2003, The cross in our context: Jesus and the suffering world, Fortress, Minneapolis, MN.

Haught, J.F., 2000, God after Darwin: A theology of evolution, Westview Press, Boulder, $\mathrm{CO}$.

Hefner, P., 1993, The human factor: Evolution, culture and religion, Fortress Press, Minneapolis.

Hick, J., 1966, Evil and the God of love, Harper \& Row, New York.

Hrdy, S.B., 2009, Mothers and others: The evolutionary origins of mutual understanding, Belknap Press, Cambridge.

Jablonka, E. \& Lamb, M.J., 2014, Evolution in four dimensions: Genetic, epigenetic, behavioral, and symbolic variation in the history of life, MIT Press, Cambridge, MA.

Jacobs, A., 2008, Original sin: A cultural history, HarperOne, New York.

Johnson, E.A., 2014, Ask the beasts: Darwin and the God of love, Bloomsbury, London.

Joyce, R., 2006, The evolution of morality, MIT Press, Cambridge, MA.

Kitcher, P., 2011, The ethical project, Harvard University Press, Cambridge, MA.

Kuyper, A., 1998, 'Evolution', in J.D. Bratt (ed.), Abraham Kuyper: A centennial reader, pp. 403-440, Eerdmans, Grand Rapids, MI.

McFague, S., 2013, Blessed are the consumers: Climate change and the practice of restraint, Fortress, Minneapolis, MN.

Messer, N., 2007, Selfish genes and Christian ethics: Theological and ethical reflections on evolutionary biology, SCM Press, London.

Moltmann, J., 1985, God in creation: An ecological doctrine of creation, SCM Press, London.

Moltmann, J., 1996, The coming of God: Christian eschatology, Fortress, Minneapolis, MN.

Murphy, N., Russell, R.J. \& Stoeger, W.R. (eds.), 2007, Physics and cosmology: Scientific perspectives on the problem of natural evil, vol. 1, Vatican Observatory Publications, Vatican City.

Nowak, M. \& Highfield, R., 2011, Super-cooperators: Altruism, evolution and why we need each other to succeed, Free Press, New York.

Peacocke, A.R., 1993, Theology for a scientific age: Being and becoming - Natural, divine, and human, Fortress, Minneapolis, MN.

Peacocke, A.R., 2001, 'The cost of new life', in J. Polkinghorne (ed.), The work of love: Creation as kenosis, pp. 21-42, Eerdmans, Grand Rapids, MI.

Peacocke, A.R., 2004, Evolution the disguised friend of faith? Selected essays, Templeton Foundation Press, Philadelphia, PA.

Peters, T. \& Hewlett, M., 2003, Evolution from creation to new creation: Conflict, conversation and convergence, Abingdon, Nashville, TN

Peterson, G.R., 2004, 'Falling up: Evolution and original sin', in P. Clayton \& S. Jeffrey (eds.), Evolution and ethics: Human morality in biological and religious perspective pp. 273-286, Eerdmans, Grand Rapids, MI.

Plantinga, C., 1995, Not the way it's supposed to be: A breviary of sin, Eerdmans, Grand Rapids, MI.

Polkinghorne, J. (ed.), 2001, The work of love: Creation as kenosis, Eerdmans, Grand Rapids, MI.
Ricoeur, P., 1967, The symbolism of evil, Beacon Press, Boston, MA

Ridley, M., 1996, The origins of virtue: Human instincts and the evolution of cooperation, Penguin, New York.

Rolston, H. III, 1999, Genes, genesis and God: Values and their origins in natural and human history, Cambridge University Press, Cambridge.

Rolston, H. III, 2010, Three big bangs: Matter-energy, life, mind, Columbia University Press, New York.

Ruether, R.R., 1992, Gaia and God: An ecofeminist theology of earth healing, Harper \& Collins, San Francisco, CA.

Ruse, M., 2006, Darwinism and its discontents, Cambridge University Press, Cambridge.

Ruse, M. \& Wilson, E.O., 1985, 'The evolution of ethics', New Scientist 108, 50-52.

Russell, R.J., 1998, 'Special providence and genetic mutation: A new defense of theistic evolution', in R.J. Russell, W.R. Stoeger \& F.J. Ayala (eds.), Evolutionary and molecular biology: Scientific perspectives on divine action, pp. 191-223, Vatican Observatory Publications, Vatican City.

Sideris, L., 2003, Environmental ethics, ecological theology and natural selection, Columbia University Press, New York.

Smith, J.K.A., 2017, 'What stands on the fall? A philosophical exploration', in J.K.A. Smith \& W.T. Cavanaugh (eds.), Evolution and the fall, pp. 48-64, Eerdmans, Grand Rapids, Ml.

Southgate, C.C.B., 2008, The groaning of creation: God, evolution and the problem of evil, Westminster John Knox Press, Louisville, KY.

Southgate, C.C.B., 2014, 'Divine glory in a Darwinian world', Zygon 49(4), 784-807. https://doi.org/10.1111/zygo.12126

Southgate, C.C.B., 2015, 'God's creation wild and violent, and our care for other animals', Perspectives on Science and Christian Faith 67(4), 245-253.

Spikins, P., 2015, How compassion made us human: The evolutionary origins of tenderness, trust and morality, Pen \& Sword Archaeology, Barnsley.

Suchocki, M., 1994, The fall to violence: Original sin in relational theology, Continuum, New York.

Van den Brink, G., 2011, 'Should we drop the fall? On taking evil seriously', in E. Van der Borght \& P. Van Geest (eds.), Strangers and pilgrims, pp. 761-777, Brill, Leiden.

Van den Brink, G., 2017, En de Aarde Bracht Voort: Christelijk Geloof en Evolutie, Boekencentrum, Utrecht.

Van Huyssteen, J.W., 2006, Alone in the world: Human uniqueness in science and theology, Eerdmans, Grand Rapids, MI.

Van Ruler, A.A., 2009, Verzameld Werk, Deel III: God, Schepping, Mens, Zonde, D. van Keulen (ed.), Boekencentrum, Zoetermeer.

Veenhof, J., 2006, Nature and grace in Herman Bavinck, transl. A.M. Wolters, Dordt College Press, Sioux Center, IA.

Ward, K., 1996, God, chance \& necessity, Oneworld Publications, Oxford.

Welker, M., 2007, 'What could Christian theology offer to the disciplines of the law?', Journal of Law and Religion 32(1), 46-52. https://doi.org/10.1017/jlr.2017.19

Williams, P., 2001, Doing without Adam and Eve: Sociobiology and original sin, Fortress, Minneapolis, MN.

Williams, R.R., 1985, 'Sin and evil', in P.C. Hodgson \& R.H. King (eds.), Christian theology: An introduction to its traditions and tasks, pp. 194-221, Fortress, Philadelphia, PA.

Wilson, E.O., 1978, On human nature, Harvard University Press, Cambridge, MA. 